\title{
Resistance to Mefenoxam and Metalaxyl Among Field Isolates of Phytophthora capsici Causing Phytophthora Blight of Bell Pepper
}

\author{
Gregory Parra and Jean Beagle Ristaino, Department of Plant Pathology, North Carolina State University, Ra- \\ leigh 27695
}

\begin{abstract}
Parra, G., and Ristaino, J. B. 2001. Resistance to mefenoxam and metalaxyl among field isolates of Phytophthora capsici causing Phytophthora blight of bell pepper. Plant Dis. 85:10691075 .

Incidence of Phytophthora blight in bell pepper fields that were sprayed for the first time with Ridomil Gold (mefenoxam) according to labeled recommendations was higher in North Carolina in 1997 than in previous years. Mefenoxam is the more active enantiomer contained in the racemic fungicide metalaxyl. A total of 150 isolates were obtained from 17 fields at eight grower locations. Among isolates from all locations, $30 \%$ were classified as sensitive, $10 \%$ as intermediate, and 59\% were resistant to mefenoxam. Mefenoxam-resistant isolates were found in $82 \%$ of the fields sampled (14 of 17 fields). The proportion of resistant isolates in individual fields ranged from 28 to $100 \%$. The mean effective concentration $\left(\mathrm{EC}_{50}\right)$ values for mefenoxamsensitive isolates was $0.568 \mu \mathrm{g} \mathrm{ml}^{-1}$ (ranging from 0.12 to $1.1 \mu \mathrm{g} \mathrm{ml}^{-1}$ ), whereas the mean $\mathrm{EC}_{50}$ value for mefenoxam-resistant isolates was $366.5 \mu \mathrm{g} \mathrm{ml}^{-1}$ (ranging from 3 to $863 \mu \mathrm{g} \mathrm{ml}^{-1}$ ). The mean $\mathrm{EC}_{50}$ value for metalaxyl-sensitive isolates was $0.27 \mu \mathrm{g} \mathrm{ml}^{-1}$ (ranging from 0.00002 to 1.3 $\mu \mathrm{g} \mathrm{ml}^{-1}$ ) and for metalaxyl-resistant isolates was $470.34 \mu \mathrm{g} \mathrm{ml}^{-1}$ (ranging from 10 to $966 \mu \mathrm{g} \mathrm{ml}^{-}$ $\left.{ }^{1}\right)$. The greatest proportion of resistant isolates came from fields where mefenoxam was used alone rather than in combination with other fungicides. Both mating types were found among resistant isolates, suggesting that these isolates may persist in soil in subsequent years. Field isolates of Phytophthora capsici resistant to mefenoxam on pepper have not been reported previously and now pose new challenges for management of this important disease.
\end{abstract}

Additional keywords: epidemiology, fungicide resistance, fungicide sensitivity, Phytophthora root and crown rot

Phytophthora blight, caused by the oomycete plant pathogen Phytophthora capsici, is an important disease of bell pepper and cucurbit crops and causes significant economic loss. The incidence of the disease has increased in recent years in the United States and worldwide (19,35). P. capsici can infect all parts of the plant and the pathogen can be dispersed within the soil, with surface water, and via water splashing from the soil to foliage (36). The pathogen has both a sexual and asexual life cycle, thus making disease management difficult. Disease is often spatially aggregated in fields and initial disease foci can quickly initiate new foci via pathogen spread in surface water (36). Management of $P$. capsici currently relies on modifications in cultural practices, crop rotation,

Corresponding author: J. B. Ristaino

E-mail: Jean_Ristaino@ncsu.edu

Funding for the research was provided in part by the North Carolina Vegetable Growers Association, the North Carolina Agricultural Research Service, and Syngenta Chemical Corporation.

Accepted for publication 14 June 2001.

Publication no. D-2001-0802-01R

(C) 2001 The American Phytopathological Society and judicious use of selective fungicides (35).

The phenylalamide fungicide metalaxyl (trade name: Ridomil; Syngenta, Greensboro, NC) provides systemic protection against oomycete pathogens $(7,8,40)$. Metalaxyl was introduced in 1977 and provided excellent control of Phytophthora diseases (40). Its benefits included systemic activity, which enabled growers to extend spray intervals when used alone in disease management programs (38). Metalaxyl has been used extensively for control of many different oomycete pathogens, including $P$. infestans, Peronospora tabacina, and Bremia lactucae (31). The intensive use of metalaxyl led to the rapid selection for metalaxyl-resistant strains of Phytophthora infestans in Europe within 1 year of its introduction $(10,13,38)$. This was primarily due to the use of metalaxyl as a curative on large populations of $P$. infestans (30). In the United States, isolates of $P$. infestans resistant to metalaxyl were first reported in Washington State in 1991 $(11,12)$. Isolates of $P$. infestans resistant to metalaxyl also have been recovered from nontreated fields, demonstrating the importance of migration of resistant isolates of $P$. infestans in disease spread $(6,16,18,23)$. Metalaxyl resistance has been reported among many oomycete pathogens, includ- ing Plasmopara viticola, Pseudoperonospora cubensis, Peronospora tabacina, B. lactucae, and Pythium spp. (31). As a result, metalaxyl was removed from some markets until new management strategies were deployed, including its use in combination with other fungicides (38).

Metalaxyl historically has been used to control the soil and crown (stem) rot phase of Phytophthora blight on bell pepper $(20,21,28,32,36,39)$. In the early 1990 s, metalaxyl received a section 3 Federal registration for the control of Phytophthora blight of peppers in the United States. Recently, metalaxyl was replaced with mefenoxam (trade name: Ridomil Gold; Syngenta), the active enantiomer contained in the racemic fungicide metalaxyl. The fungicide is applied at frequencies similar to those used with metalaxyl, but at lower rates. In 1997, mefenoxam was widely used for the first time in field production of bell peppers in North Carolina.

Resistance of isolates of Phytophthora capsici to metalaxyl has been induced in laboratory studies by chemical mutagenesis, ultraviolet irradiation, or exposure to sublethal concentrations of metalaxyl (1,35). Metalaxyl-resistant isolates of $P$. capsici that were cross-resistant in in vitro studies to other phenylamide fungicides also have been observed. However, crossresistance has not been observed in this pathogen to different classes of fungicides $(1,3)$. Adaptive resistance of isolates of $P$. capsici to metalaxyl was demonstrated in vitro after successive transfer on metalaxyl-amended media, but some isolates lost their insensitivity after successive transfer on media amended with sublethal concentrations of metalaxyl (4). It was suggested that sublethal exposure of propagules to the compound in soil might occur. Based on these studies and the documented cases of field resistance to metalaxyl in other oomycetes, it was predicted that field resistance to metalaxyl by $P$. capsici was likely (5). Despite results from laboratory studies, development of fungicide resistance in $P$. capsici, which has an important soilborne phase, has been slower to develop than in species of Phytophthora that are primarily dispersed aerially and infect foliage.

Production of peppers in the Southeast can require frequent fungicide applications to ensure a quality harvest and, therefore, greatly increase the risk of resistance development. In the spring and summer of 
1997, an alarming increase in Phytophthora blight occurred in North Carolina bell pepper fields that were sprayed with mefenoxam. Many of the growers whose fields were affected had applied mefenoxam for the first time in 1997 for the management of Phytophthora blight. High disease severity in fungicide-treated fields indicated the possibility of mefenoxam resistance in field populations of $P$. capsici in North Carolina and elsewhere $(25,26,29)$. The objectives of this research were to collect isolates of $P$. capsici from fields where disease control failures had occurred in North Carolina and New Jersey and to determine the in vitro sensitivity of these isolates to mefenoxam. In addition, the mating type and pathogenicity of the isolates were examined. Evaluation of the metalaxyl sensitivity of isolates of $P$. capsici collected in the same pepper-growing region of North Carolina prior to 1997 was also conducted. A preliminary report of this research has been published (33).

\section{MATERIALS AND METHODS}

Culture collection and maintenance. Plants infected with $P$. capsici were collected from bell pepper fields at 13 locations among seven farms in North Carolina (Table 1). In addition, Stephen Johnston (Rutgers University, Bridgeton, NJ) provided diseased plants from four additional fields from one grower's farm in New Jersey. Initially, isolations from fields in North Carolina were from a small number of random samples submitted by county extension agents and university extension faculty. Data from our preliminary screen indicated that several isolates of $P$. capsici were highly resistant to metalaxyl (Ri- domil 2E, $240 \mathrm{mg}$ a.i./ml). Subsequently, six of the North Carolina fields were sampled more extensively, and 50 or more plants were collected from each site (Table 1). Data from the combined collections are shown in Table 1.

Sections of plant stem tissue with visible black lesions were surface disinfested in a $0.05 \% \mathrm{NaOCl}$ solution for $1 \mathrm{~min}$, rinsed three times in sterile distilled water, and plated onto Kannwisher Mitchell agar amended with $50 \mu \mathrm{g} \mathrm{ml}^{-1}$ hymexazol (24). Petri dishes were incubated for 5 to 7 days at $24^{\circ} \mathrm{C}$ in the dark and colonies with growth characteristic of $P$. capsici were transferred to clarified V8 juice agar (200 $\mathrm{ml}$ of $\mathrm{V} 8$ clarified juice, $800 \mathrm{ml}$ of deionized water, and $17 \mathrm{~g}$ of agar). V8 juice was clarified by filtration through a Whatman number 4 filter paper after the addition of 2 $\mathrm{g}$ of $\mathrm{CaCO}_{3}$, followed by centrifugation at $4,340 \times g$ for $10 \mathrm{~min}$. The pathogen was identified based on colony morphology and sporangial characteristics.

Polymerase chain reaction identification of isolates. A subset of the isolates was tested by polymerase chain reaction (PCR) to confirm identification as $P$. capsici. DNA was extracted from mycelium of the isolates by a $\mathrm{NaOH}$ method (42). DNA was also extracted from 16 previously identified isolates of $P$. capsici in our collection for comparison (37). DNA was amplified via PCR utilizing the $P$. capsici specific primer, PCAP. The PCAP primer, in combination with the universal primer ITS1, amplifies an approximately 172-bp fragment of ribosomal DNA from isolates of $P$. capsici (37). PCR products were separated by gel electrophoresis on $2 \%$ agarose gels. Product size was determined by comparison with a molecular size standard included in each gel.

Fungicide sensitivity and $\mathrm{EC}_{\mathbf{5 0}}$ assays. Thirty-five isolates of $P$. capsici collected prior to 1997 were assayed for sensitivity to metalaxyl. These isolates were collected from pepper, tomato, pumpkin, eggplant, cucumber, and squash (Table 2). Stock cultures from the isolates were grown on V8 juice agar for 10 days in ambient light. Agar disks (6 $\mathrm{mm}$ in diameter) were removed from actively growing margins of the cultures and transferred to clarified V8 juice agar media previously amended with metalaxyl (Ridomil 2E, $240 \mathrm{mg}$ a.i. $\mathrm{ml}^{-1}$ ) at $0,0.1,1.0,5.0,10.0$, or $100 \mu \mathrm{g} \mathrm{ml}^{-1}$. The fungicide (emulsifiable concentrate) was diluted in sterile water before adding it to the autoclaved media. Three replicate petri dishes per fungicide level were tested for each isolate. Dishes were incubated at $24^{\circ} \mathrm{C}$ for 7 to 10 days in constant light. Colony diameters of $P$. capsici were measured in two directions for each individual dish, averaged, and compared to average colony diameters from non-amended media. The percent growth of each isolate relative to the nonamended control was plotted against the $\log _{10}$ of the metalaxyl concentration. The effective concentration $\left(\mathrm{EC}_{50}\right)$ for each isolate was calculated. Analysis involved fitting regression lines for isolate radial growth values expressed as a percentage of the nonamended controls plotted against $\log _{10}$ of the metalaxyl concentration for each isolate. The point on the regression line at which $50 \%$ of the isolate growth was inhibited is the $\mathrm{ED}_{50}$ value. Statistical analysis was conducted with the Statistical Analysis System (SAS Institute, Inc., Cary NC) as described below.

Table 1. Sensitivity of isolates of Phytophthora capsici collected in 1997 from bell pepper fields in North Carolina and New Jersey to the fungicide mefenoxam

\begin{tabular}{|c|c|c|c|c|c|c|c|c|}
\hline \multirow[b]{2}{*}{ Farm, county or state } & \multirow[b]{2}{*}{ Field } & \multicolumn{2}{|c|}{ Number collected } & \multicolumn{3}{|c|}{ Number of isolates ${ }^{a}$} & \multirow[b]{2}{*}{ Resistant (\%) } & \multirow[b]{2}{*}{ Fungicide $^{\text {b }}$} \\
\hline & & Plants & Isolates & Sensitive & Intermediate & Resistant & & \\
\hline 1, Wilson, NC & 1 & 50 & 28 & 12 & 6 & 10 & 36 & RG \\
\hline \multirow[t]{4}{*}{ 2, Sampson, NC } & 1 & 62 & 13 & 4 & 2 & 7 & 53 & $\mathrm{R} 2 \mathrm{E}, \mathrm{M} / \mathrm{Cu}$ \\
\hline & 2 & 54 & 8 & 3 & 2 & 3 & 38 & RG \\
\hline & 3 & 62 & 20 & 6 & 2 & 12 & 60 & MBR, RG \\
\hline & 4 & 7 & 4 & 2 & 0 & 2 & 50 & RG \\
\hline \multirow{2}{*}{ 3, Sampson, NC } & 1 & 60 & 26 & 5 & 0 & 21 & 81 & RG \\
\hline & 2 & 57 & 15 & 1 & 0 & 14 & 93 & RG \\
\hline \multirow{3}{*}{ 4, Sampson, NC } & 1 & 7 & 2 & 2 & 0 & 0 & 0 & Chl, R2E \\
\hline & 2 & 8 & 5 & 3 & 0 & 2 & 40 & $\mathrm{RG} / \mathrm{Cu}$ \\
\hline & 3 & 1 & 1 & 1 & 0 & 0 & 0 & RG \\
\hline 5, Sampson, NC & 1 & 1 & 1 & 0 & 0 & 1 & 100 & RG \\
\hline 6 , Greene, NC & 1 & 8 & 7 & 4 & 1 & 2 & 29 & RG 3x \\
\hline 7, Sampson, NC & 1 & 1 & 1 & 1 & 0 & 0 & 0 & No RG \\
\hline \multirow[t]{4}{*}{ 8, New Jersey } & 1 & 3 & 3 & 0 & 0 & 3 & 100 & RG \\
\hline & 2 & 1 & 1 & 0 & 0 & 1 & 100 & RG \\
\hline & 3 & 5 & 5 & 0 & 1 & 4 & 80 & RG \\
\hline & 4 & 10 & 10 & 2 & 0 & 8 & 80 & RG \\
\hline Total & 17 & 397 & 150 & 46 & 14 & 90 & $\ldots$ & $\ldots$ \\
\hline
\end{tabular}

a Isolates were characterized as sensitive to mefenoxam if colony growth at $5 \mu \mathrm{g} \mathrm{m} \mathrm{m}^{-1}$ was less than $40 \%$ of the isolate's growth on the nonamended media. Intermediate isolates exhibited growth greater than $40 \%$ of the nonamended media control at $5 \mu \mathrm{g} \mathrm{ml}^{-1}$, but less than $40 \%$ of the nonamended media control with mefenoxam at $100 \mu \mathrm{g} \mathrm{ml} \mathrm{m}^{-1}$. Resistant isolates exhibited growth greater than $40 \%$ of the nonamended media control with mefenoxam at $100 \mu \mathrm{g}$ $\mathrm{ml}^{-1}$.

${ }^{\mathrm{b}}$ Use history during season: $\mathrm{RG}=$ Ridomil Gold (mefenoxam), R2E = Ridomil 2E (metalaxyl), M/Cu = Maneb/copper, MBR = methyl bromide/Chloropicrin), $\mathrm{Chl}=$ Chloropicrin. 
In all, 150 isolates collected during the summer of 1997 were evaluated for resistance to mefenoxam (Table 1). Isolates were grown on clarified V8 juice agar for 10 days at $24^{\circ} \mathrm{C}$ in ambient light prior to use. Clarified V8 juice agar was amended with mefenoxam (Ridomil Gold EC, 480 $\mathrm{mg}$ a.i. $\mathrm{ml}^{-1}$ ) at 0,5 , and $100 \mu \mathrm{g} \mathrm{ml}^{-1}$ (11). Solutions of the fungicide were prepared in sterile water prior to amendment of the agar media. Agar disks from each isolate were transferred onto two replicate petri dishes of media amended with mefenoxam at each of the three fungicide concentrations. The dishes were incubated at $24^{\circ} \mathrm{C}$ in ambient light for 7 to 10 days. Colony growth was determined by measuring two colony diameters for each replicate dish and calculating the mean diameter for each isolate. The experiment was repeated two times for each isolate.

Isolates were characterized as sensitive if colony growth on media amended with $5 \mu \mathrm{g}$ $\mathrm{ml}^{-1}$ of metalaxyl or mefenoxam was less than $40 \%$ of the isolates' growth on nonamended media. Intermediate isolates exhibited growth on media amended with $5 \mu \mathrm{g}$ $\mathrm{ml}^{-1}$ greater than $40 \%$ of that on nonamended media, but growth on media amended with $100 \mu \mathrm{g} \mathrm{ml}^{-1}$ less than $40 \%$ of that on nonamended media. Resistant iso-

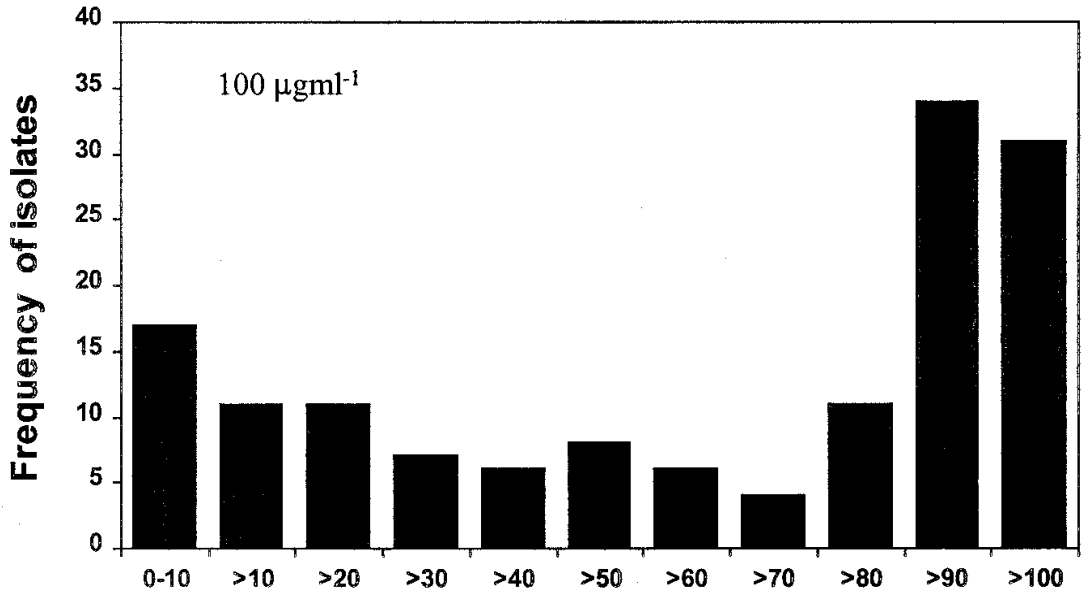

\section{Growth on mefenoxam amended media (percent of control)}

Fig 1. Frequency of mefenoxam resistance in isolates of Phytophthora capsici collected in 1997 in 13 locations in North Carolina and four locations in New Jersey. Isolates were grouped according to percentage of growth on mefenoxam-amended media at $100 \mu \mathrm{g} \mathrm{ml}^{-1}$ relative to nonamended control. Isolates with intermediate resistance had growth with mefenoxam at $100 \mu \mathrm{g} / \mathrm{ml}$ less than $40 \%$ of that on nonamended media. Resistant isolates had growth with mefenoxam at $100 \mu \mathrm{g} / \mathrm{ml}$ greater than $40 \%$ of that on nonamended media.

Table 2. Isolate designation, county, state, host, year of isolation, mating type and effective concentration (EC $\left.{ }_{50}\right)$ value on metalaxyl-amended media of isolates of Phytophthora capsici collected from pepper, cucumber, squash, pumpkin, eggplant, and tomato between 1987 and 1996

\begin{tabular}{|c|c|c|c|c|c|c|}
\hline \multirow[b]{2}{*}{ Isolate number, name } & \multirow[b]{2}{*}{ County, state } & \multirow[b]{2}{*}{ Host } & \multirow[b]{2}{*}{ Year isolated } & \multirow[b]{2}{*}{ Mating type } & \multicolumn{2}{|c|}{$\mathrm{EC}_{50}\left(\mu \mathrm{g} \mathrm{ml}^{-1}\right)$} \\
\hline & & & & & Mean & Range $^{\mathbf{a}}$ \\
\hline 18 Fruit & Sampson, NC & Pepper & 1989 & A1 & 0.78 & $0.54-1.39$ \\
\hline 19 War 1 & Sampson, NC & Pepper & 1989 & A1 & 1.34 & $1.11-1.7$ \\
\hline 20 War 2 & Sampson, NC & Pepper & 1989 & A1 & 0.17 & $0.17-0.17$ \\
\hline 21 RT 403\#1 & Sampson, NC & Pepper & 1989 & A1 & 0.60 & $0.53-0.7$ \\
\hline 22 RT 403 \#2 & Sampson, NC & Pepper & 1989 & A1 & 1.20 & $0.86-1.96$ \\
\hline 23 B\&W \#1 & Sampson, NC & Pepper & 1989 & A1 & 0.97 & $0.89-1.06$ \\
\hline 25 King-1 & Sampson, NC & Pepper & 1990 & A1 & 0.67 & $0.53-0.94$ \\
\hline 26 King-2 & Sampson, NC & Pepper & 1990 & A1 & 9.15 & $7.62-11.45$ \\
\hline 27 King-3 & Sampson, NC & Pepper & 1990 & A1 & 0.88 & NV \\
\hline 29 D. Wilson-1 & Sampson, NC & Pepper & 1990 & A1 & 1.32 & $1.15-1.53$ \\
\hline 30 Ruff 6-6 & Polk, NC & Pepper & 1991 & A1 & 2.09 & $1.36-4.48$ \\
\hline 31 Ruff 2-15 & Polk, NC & Pepper & 1991 & A1 & 0.74 & $0.58-1.04$ \\
\hline 32 Ruff 7-1 & Polk, NC & Pepper & 1991 & A1 & 1.19 & $0.066-5.62$ \\
\hline 33 Ruff 5-4 & Polk, NC & Pepper & 1991 & A1 & 0.73 & $0.65-0.83$ \\
\hline 34 1CA & California & Tomato & 1986 & A2 & 0.77 & $0.74-0.81$ \\
\hline 35 Tom 2 & Henderson, NC & Tomato & 1990 & A2 & 0.39 & $0.32-0.51$ \\
\hline 36 Tom 3 & Henderson, NC & Tomato & 1990 & $\mathrm{~A} 2$ & 2.94 & $2.18-4.51$ \\
\hline 37 Tom4 & Henderson, NC & Tomato & 1990 & A1 & 0.19 & NV \\
\hline 38 Tom5 & Henderson, NC & Tomato & 1990 & $\mathrm{~A} 2$ & 1.95 & $1.71-2.27$ \\
\hline 39 Pump1 & California & Pumpkin & 1986 & A2 & 0.17 & NV \\
\hline 40 Pump2 & Wake, NC & Pumpkin & 1990 & $\mathrm{~A} 2$ & 0.76 & $0.55-1.22$ \\
\hline 41 Pump3 & Wake, NC & Pumpkin & 1990 & A2 & 0.67 & $0.55-0.87$ \\
\hline 42 Flaim & New Jersey & Eggplant & 1988 & A1 & 2.58 & $2.04-3.51$ \\
\hline 52 Acorn 2 & Sampson, NC & Squash & 1988 & A2 & 0.48 & $0.41-0.58$ \\
\hline 55 But2 & Sampson, NC & Squash & 1988 & A1 & 2.66 & $2.17-3.45$ \\
\hline 57 Patti4 & Sampson, NC & Squash & 1988 & A1 & 0.89 & $0.78-1.04$ \\
\hline 59 Spag2 & Sampson, NC & Squash & 1988 & A1 & 0.53 & $0.51-0.55$ \\
\hline 62 Ginseng & Henderson, NC & Ginseng & 1991 & $\mathrm{~A} 2$ & 0.33 & $0.32-0.34$ \\
\hline 82 B92-1 & Sampson, NC & Pepper & 1982 & A1 & 2.51 & $2.06-3.23$ \\
\hline 83 B92-2 & Sampson, NC & Pepper & 1992 & $\mathrm{~A} 2$ & 0.68 & $0.54-0.89$ \\
\hline 84 K92-1 & Sampson, NC & Pepper & 1992 & A1 & 7.81 & $6.96-8.88$ \\
\hline 85 K92-2 & Sampson, NC & Pepper & 1992 & A1 & 0.73 & $0.6-0.96$ \\
\hline 87 В1HB14 & Sampson, NC & Pepper & 1993 & A1 & 0.70 & $0.47-1.43$ \\
\hline 88 B2HH4 & Sampson, NC & Pepper & 1993 & $\mathrm{~A} 2$ & 0.53 & $0.49-0.59$ \\
\hline 98 CL5-Phy2 & Sampson, NC & Cucumber & 1994 & $\mathrm{~A} 2$ & 2.60 & $2.06-3.54$ \\
\hline
\end{tabular}

${ }^{\mathrm{a}} \mathrm{NV}=$ no variation, values were the same between reps. 
lates exhibited growth on media amended with $100 \mu \mathrm{g} \mathrm{ml}^{-1}$ greater than $40 \%$ of that on nonamended media (16).

The $\mathrm{EC}_{50}$ values for sensitivity to mefenoxam were estimated for six mefenoxam-resistant (isolates numbers 317 , $363,414,428,399$, and 391) and six mefenoxam-sensitive (isolate numbers 358, 299, 376, 297, 378, and 427) isolates of $P$. capsici. Clarified V8 juice agar was amended with mefenoxam at levels of 0 , $0.1,1.0,10,100$, and $1,000 \mu \mathrm{g} \mathrm{ml}^{-1}$. Agar disks from each of the 12 isolates of $P$. capsici were placed onto two replicate plates of the mefenoxam-amended media. The plates were incubated in ambient light at $24^{\circ} \mathrm{C}$ for 7 to 10 days. Colony growth was determined by measurement of colony diameters in two directions for each replicate petri dish. The experiment was done three times for each isolate. Percent growth was determined relative to the nonamended control for each isolate. The percent growth of each isolate compared to the nonamended control was plotted against $\log _{10}$ concentration of mefenoxam. $\mathrm{EC}_{50}$ values were calculated for each isolate. The experiment was repeated substituting metalaxyl (Ridomil 2E) for mefenoxam and the $\mathrm{EC}_{50}$ values for the same 12 isolates were determined.

$\mathrm{EC}_{50}$ values were calculated for each isolate by nonlinear regression using the Statistical Analysis System Software (SAS Institute, Inc.). The log-logistic model ( $\mathrm{Pr}$ $(y>c)=1 /\left\{1+(\lambda * c)^{* *} p\right\}$, where $\mathrm{EC}_{50}=$ 1/lambda, provided the best fit of the data for mefenoxam- and metalaxyl-sensitive isolates. The Weibull distribution function $\left(\operatorname{Pr}(y>c)=\exp \left\{-1(\lambda * c)^{* *} p\right\}\right.$, where $\left.\mathrm{EC}_{50}=[(0.6931) * *(1 / p)] / \lambda\right)$, provided the best fit of the data for mefenoxam- and metalaxyl-resistant isolates.

Mating type. Mating type was determined for a subset of isolates from each field by pairing each isolate of $P$. capsici with a known A1 (isolate B1BH14) or A2 (isolate B2HH4) tester isolate. All crosses were conducted by
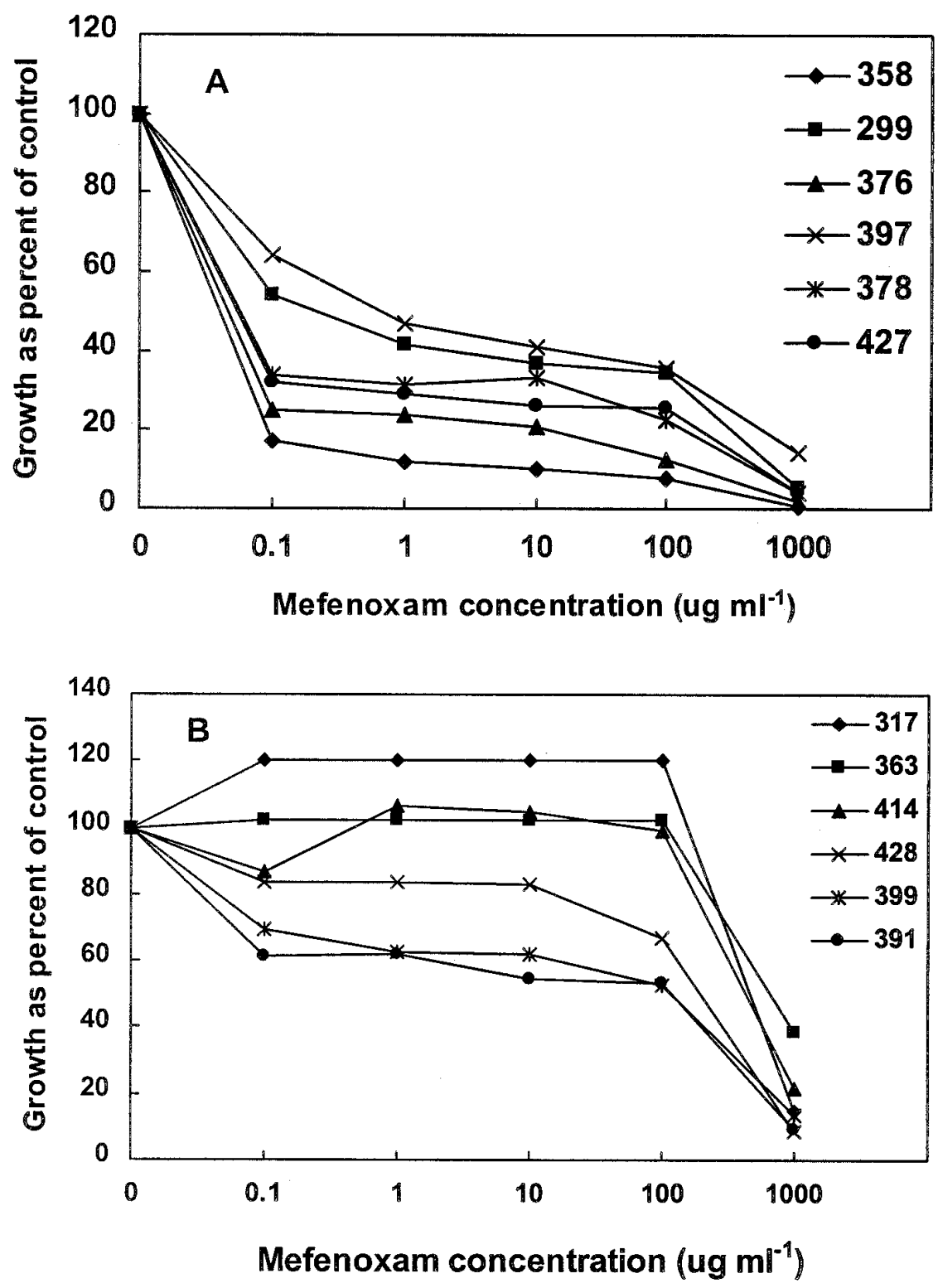

Fig 2. Growth with mefenoxam at $100 \mu \mathrm{g} / \mathrm{ml}$ expressed as a percentage of that on nonamended media versus $\log _{10}$ mefenoxam concentration of $\mathbf{A}$, six sensitive and $\mathbf{B}$, six resistant isolates of Phytophthora capsici collected in 1997. Isolates were grown on clarified V8 juice agar amended with mefenoxam at $0,0.1,1.0,10,100$, or $1,000 \mu \mathrm{g} / \mathrm{ml}$. Each line represents a different isolate

Table 3. Mean effective concentration $\left(\mathrm{EC}_{50}\right.$ ) values of six isolates of Phytophthora capsici that were sensitive or resistant to mefenoxam and metalaxyl

\begin{tabular}{|c|c|c|c|c|c|c|}
\hline \multirow[b]{2}{*}{ Isolate number $^{\mathrm{a}}$} & \multirow[b]{2}{*}{ Isolate name } & \multirow[b]{2}{*}{ Mating type } & \multicolumn{2}{|c|}{ Mefenoxam $(\mu \mathrm{g} / \mathrm{ml})$} & \multicolumn{2}{|c|}{ Metalaxyl $(\mu \mathrm{g} / \mathrm{ml})$} \\
\hline & & & Mean $\mathbf{E C}_{50}$ & Range $\mathbf{E C}_{50}$ & Mean EC E0 $_{50}$ & Range $\mathrm{EC}_{50} \mathrm{~b}$ \\
\hline \multicolumn{7}{|l|}{ Resistant } \\
\hline 414 & SH A & $\mathrm{A} 1$ & 512 & $170-840$ & 723.07 & $551-1050$ \\
\hline 391 & 2950 & A2 & 3 & $0.4-19$ & 10.16 & $4.18-23.54$ \\
\hline 317 & NJ SE & $\mathrm{A} 2$ & 863 & $\mathrm{NV}^{\mathrm{b}}$ & 877.94 & NV \\
\hline 399 & $\mathrm{SH}(\mathrm{W}) \mathrm{A}$ & A1 & 7 & $0.2-100$ & 87.34 & $10.23-170.30$ \\
\hline 363 & TriW2A & $\mathrm{A} 2$ & 787 & $400-920$ & 966 & NV \\
\hline 428 & $\mathrm{JH}(\mathrm{C}) \mathrm{E}$ & $\mathrm{ND}^{\mathrm{c}}$ & 27 & $0.5->1,000$ & 157.53 & $100.9-352.3$ \\
\hline \multicolumn{7}{|l|}{ Sensitive } \\
\hline 427 & $\mathrm{JH}(\mathrm{C}) \mathrm{G}$ & ND & 0.12 & $0.02-0.29$ & 0.0008 & 0 \\
\hline 299 & HAM & A2 & 1.00 & $0.4-2.5$ & 0.30 & $0.13-1.08$ \\
\hline 378 & $\mathrm{JH}(\mathrm{C}) \mathrm{D}$ & $\mathrm{A} 2$ & 0.12 & $0.07-0.19$ & 0.003 & 0 \\
\hline 376 & SH(HS)J & A2 & 0.94 & $0.6-1.5$ & 0.0003 & 0 \\
\hline 297 & HAM & $\mathrm{A} 2$ & 1.10 & $0.15-4.1$ & 1.33 & $0.82-3.53$ \\
\hline 358 & $\mathrm{SH}(\mathrm{HS}) \mathrm{F}$ & A1 & 0.13 & $0.08-0.2$ & 0.00002 & 0 \\
\hline
\end{tabular}

${ }^{a}$ Isolates were previously characterized as sensitive or resistant to mefenoxam on mefenoxam at 0,5 , and $100 \mu \mathrm{g} / \mathrm{ml}$.

$\mathrm{b} N \mathrm{NV}=$ no variation observed.

${ }^{\mathrm{c}} \mathrm{ND}=$ not described 
placing agar disks removed from 1-week-old cultures of each isolate on clarified V8 juice agar and incubating them for 21 to 28 days in the dark at $24^{\circ} \mathrm{C}$. In each test, the absence of oospores at the interface between colonies indicated the same mating type. The positive control was a cross between two tester isolates of opposite mating type, whereas the negative control was a cross between isolates of the same mating type.

\section{RESULTS}

PCR identification of isolates. Isolates originally identified as $P$. capsici through the use of selective media, colony, and sporangial morphology were confirmed as $P$. capsici through the use of PCR and the PCAP primer. All of the isolates tested with the PCR technique yielded the expected 172-bp product.

Fungicide sensitivity and $\mathbf{E C}_{50}$ values for isolates collected between 1987 and 1994. No isolates of $P$. capsici collected between 1987 and 1994 were resistant to metalaxyl (Table 2). In all, 23 isolates had $\mathrm{EC}_{50}$ values between 0.1 and $1.0 \mu \mathrm{g}$ $\mathrm{ml}^{-1}, 10$ isolates had $\mathrm{EC}_{50}$ values between 1.0 and $5.0 \mu \mathrm{g} \mathrm{ml}^{-1}$, and 2 isolates had $\mathrm{EC}_{50}$ values between 5 and $10 \mu \mathrm{g} \mathrm{ml}^{-1}$ (Table 2). These two isolates were classified as intermediate in sensitivity to metalaxyl and came from the same grower field in different years with a history of metalaxyl use.

Fungicide sensitivity and $\mathrm{EC}_{50}$ values for isolates collected in 1997. Among 150 isolates of $P$. capsici collected from bell pepper fields in 1997, $30 \%$ were classified as sensitive, $10 \%$ as intermediate, and $59 \%$ as resistant to mefenoxam (Table 1). Mefenoxamresistant isolates were detected in $82 \%$ of the fields sampled (14 of 17 fields) and the percentage of resistant isolates among individual fields ranged from 29 to $100 \%$. Isolates that were sensitive to mefenoxam were also found in most fields sampled, and the percentage of sensitive isolates among individual fields was 7 to $100 \%$ (Table 1).

The largest frequency of isolates exhibited growth greater than $90 \%$ of the nonamended control on mefenoxam at $100 \mu \mathrm{g}$ $\mathrm{ml}^{-1}$. (Fig. 1). Sixty-five isolates were highly resistant to mefenoxam and exhibited enhanced growth of $90 \%$ or more on mefenoxam-amended media when compared to growth on the nonamended control. Twenty percent of the isolates exhibited enhanced growth of $100 \%$ or greater on mefenoxam at $100 \mu \mathrm{g} \mathrm{ml}^{-1}$ (Fig 1).

More plant samples were removed from three of the grower's farms where disease incidence was highest (growers 1, 2, and 3; Table 1). Growers 1, 3, and 8 applied mefenoxam to their fields during the season for management of Phytophthora spp., whereas growers 2 and 4 applied a preplant soil fumigant of methyl bromide/ chloropicrin or chloropicrin alone, fol- lowed by a combination of different fungicides, including metalaxyl (Ridomil 2E), maneb/copper, metalaxyl/copper (Ridomil 2E/copper), or mefenoxam (Ridomil Gold) centages of mefenoxam-resistant isolates $(>80 \%)$ came from fields of growers 3 and 8 , where only mefenoxam was applied (Table 1). However, in other fields where mefenoxam was used alone (growers 1 and 6 ), lower percentages of mefenoxamresistant isolates were found. A lower percentage of mefenoxam-resistant isolates (38 to 60\%) was found in fields of grower 2 , where mixtures of fungicides were used during the season (Table 1).

The mean $\mathrm{EC}_{50}$ value for a subset of six sensitive isolates collected in 1997 was $0.568 \mu \mathrm{g} \mathrm{ml}^{-1}$ and $\mathrm{EC}_{50}$ values ranged from during the season (Table 1). Highest per-

0.12 to $1.1 \mu \mathrm{g} \mathrm{ml}^{-1}$ (Table 3). The mean $\mathrm{EC}_{50}$ value for mefenoxam-resistant isolates was $366.5 \mu \mathrm{g} \mathrm{ml}^{-1}$ and $\mathrm{EC}_{50}$ values ranged from 3 to $863 \mu \mathrm{g} \mathrm{ml}^{-1}$ (Table 3 ). The relative sensitivities to mefenoxam of six sensitive and six resistant isolates are shown in Figure 2. Some of the mefenoxam-resistant isolates exhibited enhanced growth on media amended with mefenoxam at $100 \mu \mathrm{g} \mathrm{ml}^{-1}$ (Fig. 2B), while sensitive isolates had reduced growth on media with mefenoxam at $100 \mu \mathrm{g} \mathrm{ml}^{-1}$; Fig. 2A).

The relative sensitivities of six sensitive and six resistant isolates of $P$. capsici to metalaxyl are shown in Figure 3. The mean $\mathrm{EC}_{50}$ value for the sensitive isolates was $0.27 \mu \mathrm{g} \mathrm{ml}^{-1}$ and $\mathrm{EC}_{50}$ values ranged from .00002 to $1.33 \mu \mathrm{g} \mathrm{ml}^{-1}$ (Table 3 ). The mean
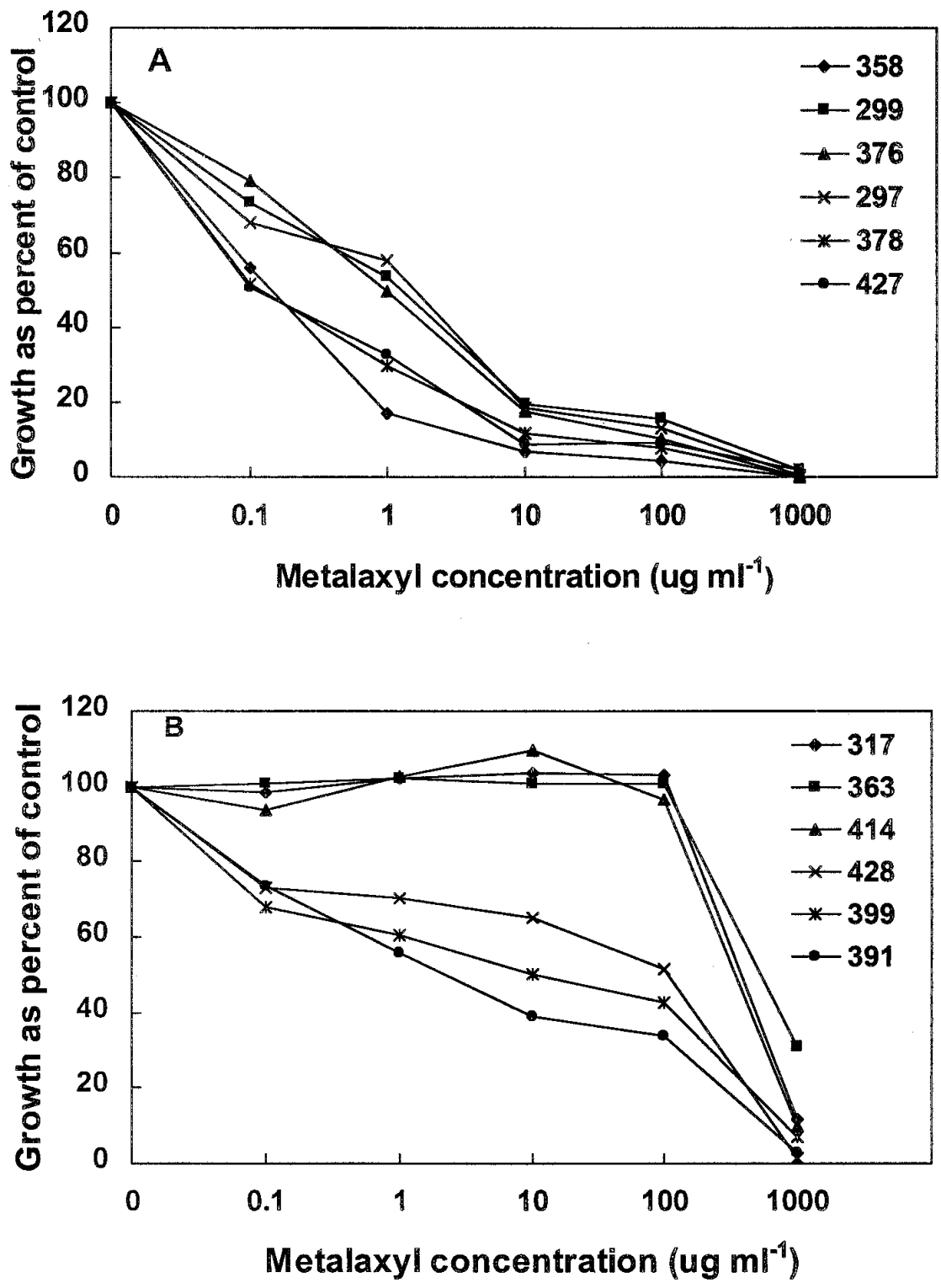

Fig 3. Growth with metalaxyl at $100 \mu \mathrm{g} / \mathrm{ml}$ expressed as a percentage of that on nonamended media versus metalaxyl concentration of $\mathbf{A}$, six sensitive and $\mathbf{B}$, six resistant isolates of Phytophthora capsici collected in 1997. Isolates were grown on clarified V8 juice agar amended with metalaxyl at 0 , $0.1,1.0,10,100$, or $1,000 \mu \mathrm{g} \mathrm{ml}^{-1}$. Each line represents a different isolate. 
$\mathrm{EC}_{50}$ value for resistant isolates was $470.34 \mu \mathrm{g} \mathrm{ml}^{-1}$ and $\mathrm{EC}_{50}$ values ranged from 10 to $966 \mu \mathrm{g} \mathrm{ml}^{-1}$ (Table 3).

Mating type determination. A1 and A2 mating types were recovered from most of the fields that were sampled in North Carolina, as well as the fields in New Jersey (Table 4). In nine fields located on four grower farms, both $\mathrm{A} 1$ and $\mathrm{A} 2$ mating types were found among mefenoxam-resistant isolates.

\section{DISCUSSION}

Isolates of $P$. capsici collected between 1987 and 1994 from a range of vegetable crops in North Carolina fields were highly isolates of $P$. capsici collected in fields in 1997 in North Carolina and New Jersey have developed resistance to the fungicide mefenoxam. Mefenoxam-resistant isolates were widespread in North Carolina fields and occurred in 10 of 13 fields sampled. Metalaxyl-resistant isolates were initially discovered in 1997 via routine screening for metalaxyl sensitivity of isolates obtained from the Plant Disease and Insect Clinic at North Carolina State University. Isolates that were resistant to metalaxyl were also highly resistant to mefenoxam. However, mean $\mathrm{EC}_{50}$ values were higher for metalaxyl than mefenoxam for all isolates tested. Metalaxyl has been used past in both regions, which may explain the higher $\mathrm{EC}_{50}$ values for metalaxyl. Mefenoxam is applied at lower rates in the field than metalaxyl, but contains the sensitive to metalaxyl. Our data show that more frequently than mefenoxam in the

more active enantiomer of metalaxyl. The rate of resistance development in populations of the pathogen may vary for the two fungicides.

The high percentage of mefenoxam-resistant isolates collected was surprising considering that neither metalaxyl- nor mefenoxam-resistant isolates of $P$. capsici had been reported prior to 1997 in the field to our knowledge. After our initial report (33), isolates of $P$. capsici collected between 1992 to 1997 from greenhouse peppers grown in Italy were screened by others and intermediate levels of resistance to metalaxyl were reported (34). These workers suggested that caution should be exercised in the use of metalaxyl in greenhouse-grown pepper crops in Italy. More recently, mefenoxam resistance has been reported in Michigan on field-grown cucurbits and on peppers and cucurbits in Georgia $(25,26,29)$.

A shift in sensitivity to mefenoxam within populations of $P$. capsici has occurred in bell pepper fields in North Carolina and New Jersey in a relatively short period of time. Due to the risk-averse nature of many growers, it is possible that more fields have received applications of mefenoxam as disease incidence has increased in recent years with high rainfall conditions in many areas of the northeast and southeast. Frequently, bell pepper production in North Carolina is followed by cucurbit production in the same field during the same season. Metalaxyl and mefenoxam are also used for disease management in adjacent tobacco fields. In

Table 4. Isolates of Phytophthora capsici classified by mefenoxam sensitivity and mating type within populations from different locations on eight grower farms in North Carolina and New Jersey in 1997

\begin{tabular}{|c|c|c|c|c|c|c|c|}
\hline \multirow[b]{3}{*}{ Grower } & \multirow[b]{3}{*}{ Field } & \multicolumn{6}{|c|}{ Number of isolates ${ }^{a}$} \\
\hline & & \multicolumn{2}{|c|}{ Sensitive } & \multicolumn{2}{|c|}{ Intermediate } & \multicolumn{2}{|c|}{ Resistant } \\
\hline & & $\mathbf{A 1}^{\mathrm{b}}$ & $\mathbf{A} 2^{\mathbf{b}}$ & A1 & A2 & A1 & A2 \\
\hline 1 & 1 & 3 & 9 & 4 & 1 & 6 & 3 \\
\hline \multirow[t]{4}{*}{2} & 1 & 2 & 2 & 1 & 1 & 3 & 1 \\
\hline & 2 & 1 & 0 & 2 & 0 & 2 & 0 \\
\hline & 3 & 2 & 4 & 1 & 1 & 6 & 5 \\
\hline & 4 & 0 & 2 & 0 & 0 & 1 & 1 \\
\hline \multirow[t]{2}{*}{3} & 1 & 4 & 1 & 0 & 0 & 11 & 4 \\
\hline & 2 & 0 & 1 & 0 & 0 & 9 & 5 \\
\hline \multirow[t]{3}{*}{4} & 1 & 2 & 0 & 0 & 0 & 0 & 0 \\
\hline & 2 & 0 & 2 & 0 & 0 & 1 & 0 \\
\hline & 3 & 1 & 0 & 0 & 0 & 0 & 0 \\
\hline 5 & 1 & 0 & 0 & 0 & 0 & 1 & 0 \\
\hline 6 & 1 & 2 & 1 & 0 & 0 & 0 & 2 \\
\hline 7 & 1 & 0 & 1 & 0 & 0 & 0 & 0 \\
\hline \multirow[t]{4}{*}{8} & 1 & 0 & 0 & 0 & 0 & 1 & 2 \\
\hline & 2 & 0 & 0 & 0 & 0 & 1 & 0 \\
\hline & 3 & 0 & 0 & 0 & 1 & 2 & 2 \\
\hline & 4 & 2 & 0 & 0 & 0 & 2 & 2 \\
\hline Total & 19 & 23 & 8 & 4 & 46 & 27 & $\ldots$ \\
\hline
\end{tabular}

${ }^{a}$ Isolates were characterized as sensitive to mefenoxam if colony growth at $5 \mu \mathrm{g} \mathrm{ml}^{-1}$ was less than $40 \%$ of the isolate's growth on the nonamended control media. Intermediate isolates exhibited growth greater than $40 \%$ of the nonamended media control at $5 \mu \mathrm{g} \mathrm{ml}^{-1}$, but less than $40 \%$ of the nonamended media control with mefenoxam at $100 \mu \mathrm{g} \mathrm{ml}{ }^{-1}$. Resistant isolates exhibited growth greater than $40 \%$ of the nonamended media control with mefenoxam at $100 \mu \mathrm{g} \mathrm{ml}^{-1}$.

${ }^{b}$ A1 indicates A1 mating type and A2 indicates A2 mating type determined by crosses with known tester isolates. addition, tobacco fields where phenylamide fungicides are used are rotated into vegetable production. Intensive use of phenylamide fungicides has been shown to rapidly select for resistance in other oomycetes (10). Other work on nonoomycete pathogens has demonstrated that pathogens can become more resistant to a fungicide when it is used frequently over an extended period of time (43).

Some mefenoxam-resistant isolates were not effectively controlled and were pathogenic on plants in greenhouse assays when treated with labeled rates of the fungicide (J. B. Ristaino, unpublished data). Further research is needed to determine whether mefenoxam-resistant isolates are more fit than sensitive isolates and to measure their aggressiveness on plants. Metalaxyl can promote growth of some resistant isolates of $P$. infestans and can cause normally heterothallic single mating type isolates to form oospores in culture $(41,44)$. Some studies have demonstrated that metalaxylresistant isolates of $P$. infestans are more fit than sensitive isolates $(6,8)$. However, other studies have suggested that no correlation exists between fitness and metalaxyl resistance in $P$. infestans $(17,27)$. Some of the mefenoxam-resistant isolates of $P$. capsici in our study grew to a greater extent than the nonamended controls in the presence of mefenoxam (Fig. 1). Variation in fitness could occur among isolates of P. capsici and fungicide resistance may not present a fitness cost in $P$. capsici $(17,25)$. The frequency of mefenoxam-resistant isolates of $P$. capsici from cucurbits did not decrease over a period of 2 years in the absence of mefenoxam use in Michigan (26).

Oospores are known to play a role in the survival of $P$. capsici in the field (35). Both mating types of $P$. capsici were found among resistant isolates within 9 of 17 grower fields sampled. Oospores survive in soil; therefore, mefenoxam-resistant isolates may persist for prolonged periods and cause disease in subsequent years in the absence of selection pressure from fungicide use. Further studies are needed to test individual fitness components of sensitive and resistant isolates in quantitative assays in vivo and in soil. Mefenoxam-resistant, intermediate, and mefenoxam-sensitive isolates of $P$. capsici were found in a single cucurbit fruit in Michigan and oospore progeny derived from isolates from those fruit exhibited all six mefenoxam sensitivity and mating type combinations (25). Sexual reproduction of the pathogen enhances genetic variation and may enhance survival of resistant isolates (25).

It is believed that the mode of action of metalaxyl is by the selective inhibition of ribosomal RNA synthesis $(8,9,15)$. RNA polymerase is the target site for metalaxyl and an alteration of this target site can lead to resistance in some oomycete pathogens (9). Genetic studies of $P$. infestans and $P$. sojae have indicated that resistance is 
linked to a single dominant gene, with variations in resistance accounted for by the influence of minor genes $(2,27)$. Recently, DNA markers that are linked to loci associated with metalaxyl resistance in isolates of $P$. infestans were reported $(14,22)$. Loci found to confer metalaxyl resistance in isolates of $P$. infestans from Mexico and the Netherlands were different than in British isolates of $P$. infestans, indicating that metalaxyl resistance may have developed independently in $P$. infestans isolates in different areas of the world (14). A single target site for metalaxyl resistance in $P$. infestans is highly unlikely (22). Mefenoxam sensitivity in isolates of $P$. capsici from cucurbits is controlled by a single, incompletely dominant gene that is not linked to mating type (25). Further work is needed to examine the genetic mechanisms of mefenoxam resistance in pepper isolates of $P$. capsici and to determine whether the same or different loci confer resistance in populations of $P$. capsici found in different areas or on different hosts (25).

Management of Phytophthora blight in bell pepper will continue to rely on integrated approaches. Phenylamide fungicides should not be used for disease management in fields where mefenoxam-resistant isolates have been found. Alternative, low-risk fungicides with different modes of action will be needed in problem fields. Phytophthora blight can be most effectively managed through the use of resistant cultivars and cultural practices, including water management and the use of cover crops (35).

\section{ACKNOWLEDGMENTS}

We thank extension faculty members S. Johnston (Rutgers University), F. Louws and G. Holmes (North Carolina State University), and agents W. Jester and A. Thornton (North Carolina State University) for providing some of the plant samples for assay from grower fields; and L. Sujkowski and R. French for screening populations of $P$. capsici collected prior to 1997.

\section{LITERATURE CITED}

1. Abdellaoui-Maane, S., Sing, J. M., Sandrenan, P., and Bonpeix, G. 1988. Fosetyl-Al is effective against mutants of $P$. capsici resistant to metalaxyl. Cryptogam. Mycol. 9:47-56.

2. Bhat, R. G., McBlain, B. A., and Schmitthenner, A. F. 1993. The inheritance of resistance to metalaxyl and to fluorophenylalanine in matings of homothallic Phytophthora sojae. Mycol. Res. 97:865-870.

3. Bower, L. A., and Coffey, M. D. 1985. Development of laboratory tolerance to phosphorus acid, and fosetyl-AL, and metalaxyl in Phytophthora capsici. Can. J. Plant Pathol. 7:1-6.

4. Bruin, G. C. A., and Edington, L. V. 1981. Adaptive resistance in Peronosporales to metalaxyl. Can. J. Plant Pathol. 3:201-206.

5. Bruin, G. C. A., and Edington, L. V. 1982. Induction of fungal resistance of metalaxyl by ultraviolet irradiation. Phytopathology 72:476-480.

6. Cohen, Y., and Reuveni, M. 1983. Occurrence of metalaxyl-resistant isolates of Phytophthora infestans in potato fields in Israel. Phytopathology 73:925-927.

7. Cohen, Y., Reuveni, M., and Eyal, H. 1979. The systemic antifungal activity of Ridomil against Phytophthora infestans on tomato plants. Phytopathology 69:645-649.

8. Davidse, L. C. 1995. Phenylamide fungicides. Biochemical action and resistance. Pages 347354 in: Modern Selective Fungicides: Properties, Applications, Mechanisms of Action. H. Lyr, ed. Gustav Fisher Verlag, New York.

9. Davidse, L. C., Hofman, A. E., and Velthuis, G. C. M. 1983. Specific interference of metalaxyl with endogenous RNA polymerase activity in isolated nuclei from Phytophthora megasperma f. sp. medicaginis. Exp. Mycol. 7:344-361.

10. Davidse, L. C., Looijei, D., Turkensteen, L. J., and Van Der Wal. 1981. Occurrence of metalaxyl-resistant strains of potato blight in Dutch potato fields. Neth. J. Plant Pathol. 87:65-68.

11. Deahl. K. L., DeMuth, S. P., Linden, S. L., and Rivera-Pena, A. 1995. Identification of mating types and metalaxyl resistance in North American populations of Phytophthora infestans. Am. Potato J. 72:35-49.

12. Deahl, K. L., Inglis, D. A., and DeMuth, S. P. 1993. Testing for resistance to metalaxyl in Phytophthora infestans isolates from northwestern Washington. Am. Potato J. 70:779-795.

13. Dowley, L. J., and O'Sullivan, E. 1981. Metalaxyl-resistant strains of Phytophthora infestans (Mont.) de Bary in Ireland. Potato Res. 24:417-421.

14. Fabritius, A., Shattock, R. C., and Judelson, H. S. 1997. Genetic analysis of metalaxyl insensitivity loci in Phytophthora infestans using linked DNA markers. Phytopathology 87:1034-1040.

15. Fisher, D. J., and Hayes, A. L. 1984. Studies of mechanisms of metalaxyl fungitoxicity and resistance to metalaxyl. Crop Prot. 3:117-185.

16. Fraser, D., Shoemaker, P., and Ristaino, J. B. 1999. Characterization of isolates of Phytophthora infestans from tomato and potato in North Carolina from 1993 to 1995. Plant Dis. 83:633-638.

17. Gisi, U., and Cohen, Y. 1996. Resistance to phenylamide fungicides: a case study with Phytophthora infestans involving mating type and race structure. Annu. Rev. Phytopathol. 34:549-572.

18. Goodwin, S. B., Smart, C. D., Sandrock, R. W., Deahl, K. L., Punja, Z. K., and Fry, W. E. 1998. Genetic change within populations of Phytophthora infestans in the United States and Canada during 1994 to 1996: Role of migration and recombination. Phytopathology 88:939-949.

19. Hwang, B. K., and Kim, C. H. 1995. Phytophthora blight of pepper and its control in Korea. Plant Dis. 79:221-227.

20. Hwang, B. K., and Sung, N. K. 1989. Effect of metalaxyl on capsidiol production in stems of pepper plants infected with Phytophthora capsici. Plant Dis. 73:748-751.

21. Johnston, S. A. 1982. Control of the crown rot phase of Phytophthora blight of bell pepper with fungicides. Fungic. Nematic. Tests 37:73.

22. Judelson, H. S., and Roberts, S. 1999. Multiple loci determine insensitivity to phenylamide fungicides in Phytophthora infestans. Phytopathology 87:754-760.

23. Kadish, D., Grinberger, M., and Cohen, Y. 1990. Fitness of metalaxyl-sensitive and metalaxyl-resistant isolates of Phytophthora infestans on susceptible and resistant potato cultivars. Phytopathology 80:200-205.

24. Kannwisher, M. E., and Mitchell, D. J. 1978. The influence of a fungicide on the epidemiology of black shank of tobacco. Phytopathology 68:1760-1765.

25. Lamour, K. H., and Hausbeck, M. K. 2000. Mefenoxam insensitivity and the sexual stage of Phytophthora capsici in Michigan cucurbit fields. Phytopathology 90:396-400.
26. Lamour, K. H., and Hausbeck, M. K. 2001. The dynamics of mefenoxam insensitivity in a recombining population of Phytophthora capsici characterized with amplified fragment length polymorphisms. Phytopathology 91:553-557.

27. Lee, T. Y., Mizubuti, E., and Fry, W. E. 1999. Genetics of metalaxyl resistance in Phytophthora infestans. Fungal Genet. Biol. 26:118-130.

28. Matheron, M. E., and Matejka, J. C. 1995. Comparative activities of sodiumtetrathiocarbonate and metalaxyl on Phytophthora capsici and root and crown rot on chili pepper. Plant Dis. 79:56-59.

29. Mathis, W. L., Williams-Woodward, J., and Csinos, A. S. 1999. Insensitivity of Phytophthora capsici to mefenoxam in Georgia. (Abstr.) Phytopathology 89:S49.

30. Milgroom, M. G. 1990. A stochastic model for the initial occurrence and development of fungicide resistance in plant pathogen populations. Phytopathology 80:410-416.

31. Morton, H. V., and Urech, P. A. 1988. History of the development of resistance to phenylamide fungicides. Pages 59-60 in: Fungicide Resistance in North America. C. E. Delp, ed American Phytopathological Society Press, St. Paul, MN.

32. Papavizas, G. H., and Bowers, J. H. 1981. Comparative fungitoxicity of captafol and metalaxyl to Phytophthora capsici. Phytopathology 71:123-128.

33. Parra, G., and Ristaino, J. 1998. Insensitivity to Ridomil Gold (mefenoxam) found among field isolates of Phytophthora capsici causing Phytophthora blight on bell pepper in North Carolina and New Jersey. Plant Dis. 82:711.

34. Pennisi, A. M., Agosteo, G. E., Cacciola, S. O., Pane, A., and Faedda, R. 1998. Insensitivity to metalaxyl among isolates of Phytophthora capsici causing root and crown rot of pepper in southern Italy. Plant Dis. 82:1283.

35. Ristaino, J. B., and Johnston, S. B. 1999 Ecologically-based approaches to management of Phytophthora blight on bell pepper. Plant Dis. 83:1080-1089.

36. Ristaino, J. B., Larkin R. P., and Campbell, C. L. 1993. Spatial and temporal dynamics of Phytophthora epidemics in commercial bell pepper fields. Phytopathology 83:1312-1320.

37. Ristaino, J. B., Madritch, M., Trout, C. L., and Parra, G. 1998. PCR amplification of ribosomal DNA for species identification in the plant pathogen genus Phytophthora. Appl. Environ. Microbiol. 64:948-954.

38. Russell, P. E. 1995. Fungicide resistance: occurrence and management. J. Agric. Sci. (Camb.) 124:317-323.

39. Schlub, R. L., and Johnston, S. A. 1982. Control of Phytophthora on pepper using captafol and metalaxyl. Phillip. Agric. 65:215-219.

40. Schwinn, F., and Staub, T. 1995. Oomycete fungicides. Pages 323-346 in: Modern Selective Fungicides, Properties, Applications, Mechanisms of Action. H. Lyr, ed. Gustav Fischer Verlag, New York.

41. Trout, C. L., and Ristaino, J. B. 2000. Commercial fungicide formulations induce oospore formation and mating type change in Phytophthora infestans. Phytopathology 90:1201-1208.

42. Wang, H., Qi, M., and Cutler, A. J. 1993. A simple method of preparing plant samples for PCR. Nucleic Acids Res. 21:4153-4154.

43. Yasunori, T., and Ishii, H. 1998. Reduced sensitivity to Fenarimol in Japanese field strains of Venturia nashicola. Pestic. Sci. 54:150-156.

44. Zhang, S., Panaccione, D. G., and Gallegly, M. 1997. Metalaxyl stimulation of growth of isolates of Phytophthora infestans. Mycologia 89:289-292. 